J. Clin. Chem. Clin. Biochem.

Vol. 28, 1990, pp. $221-224$

(C) 1990 Walter de Gruyter \& Co

Berlin - New York

\title{
Enzyme Immunoassay of Human Cholinesterase (EC 3.1.1.8) Comparison of Immunoreactive Substance Concentration with Catalytic Activity Concentration in Randomly Selected Serum Samples from Healthy Individuals ${ }^{1}$ )
}

\author{
By A. Brock ${ }^{1}$, Vibeke Mortensen ${ }^{2}$, Anne G. Rasmussen Loft ${ }^{2}$ and B. Nørgaard-Pedersen ${ }^{2}$ \\ ${ }^{1}$ Department of Clinical Chemistry, Randers Centralsygehus, University of Aarhus, Denmark \\ ${ }^{2}$ Hormone Department, Statens Seruminstitut, Copenhagen, Denmark
}

(Received November 20, 1989/January 16, 1990)

Summary: We developed an enzyme immunoassay (ELISA) for quantitation of plasma cholinesterase substance concentrations in native plasma or serum samples. The ELISA assay is based on polyclonal (rabbit) antihuman cholinesterase and a highly specific monoclonal (mouse) antibody, with a commercially available peroxidase-conjungated (rabbit) antibody directed against mouse immunoglobulins as the signal carrier. The detected serum cholinesterase substance concentrations (mean: $4.51 \mathrm{mg} / 1, \mathrm{SD}: 0.90 \mathrm{mg} / \mathrm{l}$ ) in randomly selected serum samples from 33 healthy individuals were closely and linearly related to the corresponding catalytic activity concentrations.

\section{Introduction}

Cholinesterase (pseudocholinesterase, acylcholine acylhydrolase, EC 3.1.1.8), which is biosynthesized in the liver, occurs in plasma as a number of distinct isozymes $(1-4)$, but predominantly as a globular, tetrameric structure with a relative molecular mass of 340000 (5). Cholinesterase is eliminated from plasma with a half-life of 5-12 days (3). Catalytic activity concentrations of plasma cholinesterase are influenced by a variety of physiological and pathological conditions $(2,3,6-8)$; further, a great number of chemicals, e.g. carbamates and organophosphorus compounds (systemic insecticides), are potent inhibitors $(2,3)$. Even in healthy, unexposed individuals, substantial intra-individual variations occur $(8,9)$. A wide variety of sensitive and precise analytical tech-

\footnotetext{
1) The study was financially supported by the Aarhus Univer-
} sity Research Foundation. niques for measuring catalytic plasma cholinesterase activity concentration have been available for many years (for reviews, see Augustinusson (10), and Silk et al. (11)). In order to interpret the observed variations of plasma cholinesterase catalytic activity, it is important to determine whether a decreased catalytic activity is the result of a reduced cholinesterase substance concentration (e.g. due to reduced synthesis), or a partial inhibition of the catalytic activity (e.g. due to exposure to systemic insecticides). Information on cholinesterase substance concentrations in native plasma samples is quite scanty $(12-16)$, and previously published methods for the quantitation of plasma cholinesterase substance concentration are laborious and unsuited for large series of samples. In the present paper we describe an easy, but highly reliable enzyme immunoassay for the determination of plasma cholinesterase substance concentration and its application to randomly selected blood samples from healthy individuals. 


\section{Materials and Methods}

Catalytic activity

Plasma cholinesterase catalytic activity concentrations were measured at $37^{\circ} \mathrm{C}$, using butyrylthiocholine as substrate (8); reference values for healthy individuals, mean: $8.45 \mathrm{kU} / \mathrm{l}, \mathrm{SD}$ : $1.94 \mathrm{kU} / \mathrm{l}$.

Enzyme linked immuno sorbent assay

\section{Procedure}

Each well of a microtitre plate (Maxisorp 473709, Nunc, Kamstrup, Roskilde, Denmark) was coated overnight with $100 \mu \mathrm{l}$ polyclonal rabbit antibodies against human plasma cholinesterase (Statens Seruminstitut, Copenhagen, Denmark), diluted $1: 5000$ in $0.1 \mathrm{~mol} / 1$ carbonate buffer $\mathrm{pH} 9.6$, then washed with $300 \mu \mathrm{l}$ phosphate-buffered saline containing $1 \mathrm{~mol} / \mathrm{l}$ Tween 20 (Merck 822184), pH 7.0.

When running the assay, $100 \mu \mathrm{l}$ of sample or calibrator (Standard Human Serum, lot no. A0410 22F, Behringwerke, Marburg, FRG, containnig $5.5 \mathrm{mg} / \mathrm{l}$ immunoreactive cholinesterase, see below), prediluted $1: 400$ (samples) or $1: 300-1: 1500$ (calibrator), was incubated at room temperature for 2 hours. After washing, $100 \mu \mathrm{l}$ monoclonal (mouse) anti-human plasma cholinesterase (cell line HAH 2-1, Statens Seruminstitut, Copenhagen, Denmark), diluted 1:500 in phosphate-buffered saline with $1 \mathrm{ml} / \mathrm{l}$ Tween 20 , was added and incubated at room temperature for another hour. After a further washing step, the monoclonal mouse antibody was detected by a horse radish peroxidase-conjugated (rabbit) antibody against mouse IgG (P 260, Dakopatts, Glostrup, Denmark), diluted 1:1000. Peroxidase activity was determined by a conventional end-point reaction using $o$-phenylenediamine as substrate (17). Absorbance was read at $490 \mathrm{~nm}$.

The dose-response curve is shown in figure 1. All samples and calibrators were run in duplicate; within assay precision estimated from the deviations of duplicates: $\mathrm{CV}=1.36 \%$ $(\mathrm{N}=33)$. Coated microtitre plates were found to be uninfluenced by storage at $4{ }^{\circ} \mathrm{C}$ for at least one week. Under the described conditions, prediluted native serum samples exhibited immunoreactive cholinesterase substance concentrations which were directly proportional to the volume of sample applied.

\section{Calibration}

For final calibration, we prepared a highly purified human cholinesterase, which was quantitated according to Lowry et al. (18); the preparation showed one homogenous protein fraction in SDS polyacrylamide gel electrophoresis.

Cholinesterase from $100 \mathrm{ml}$ plasma was adsorbed by immunoaffinity chromatography, using a monoclonal antibody against human plasma cholinesterase (cell line HAH 2-1, protein A purified IgG, Statens Seruminstitut, Copenhagen, Denmark) coupled (3.6 g IgG per litre gel) to $\mathrm{CNBr}$-activated $\mathrm{Se}$ pharose 4B (Pharmacia-LKB, Uppsala, Sweden). Cholinesterase was desorbed with TRIS-buffered $4.5 \mathrm{~mol} / 1 \mathrm{MgCl}_{2}, \mathrm{pH} 7.5$, and further purified by FPLC on a Mono Q HR 5/5 column (Pharmacia-LKB, Uppsala, Sweden), using a linear salt gradient of ammonium acetate $(0.05-0.50 \mathrm{~mol} / \mathrm{l}, \mathrm{pH} 8.0)$. Using bovine serum albumin (Sigma A-4503, lot no. 98F-0047) 50 $\mathrm{mg} / \mathrm{l}$ in $0.28 \mathrm{~mol} / \mathrm{l}$ ammonium acetate (same as the fractions containing cholinesterase) as reference, the protein concentration of the purified cholinesterase was determined to be $33 \mathrm{mg} / 1$ (18). Based on this protein concentration and the immunoreactivity of the purified cholinesterase, the immunoreactive cholinesterase substance concentration of the daily calibration material (Standard Human Serum, lot. no. A0410 22F, Behringwerke, FRG) was determined to be $5.5 \mathrm{mg} / \mathrm{l}$.

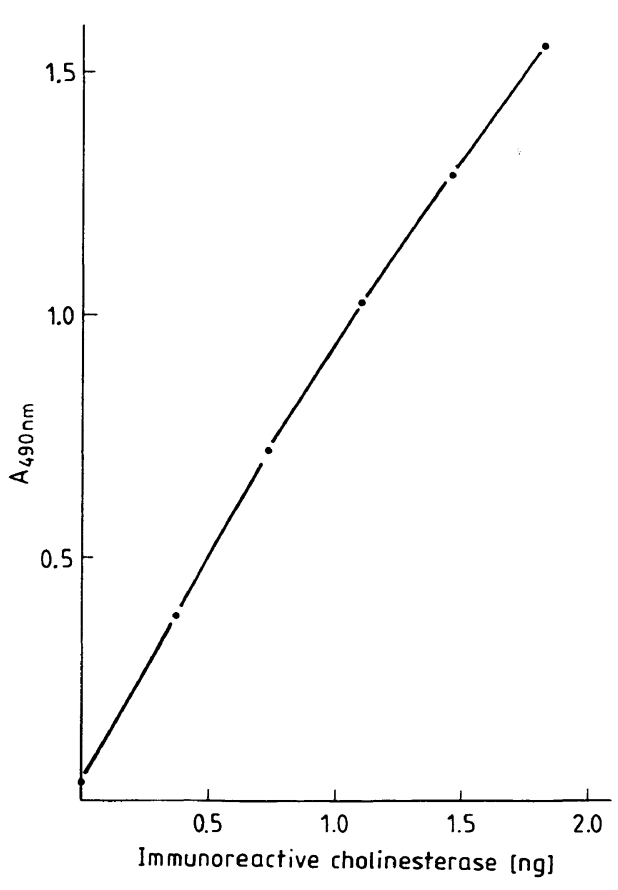

Fig. 1. Enzyme immunoassay of human plasma cholinesterase: calibration curve.

\section{Specificity}

The specificity of the monoclonal anti-human plasma cholinesterase antibody, HAH 2-1, was assessed by crossed immunoelectrophoresis (19), stained for catalytic cholinesterase activity, and examined for immunoreactive cholinesterase. The monoclonal antibody HAH 2-1 reacted exclusively with the immuno-precipitate possessing catalytic cholinesterase activity (fig. 2). In gel filtration experiments (Sephacryl S-300, Pharmacia-LKB, Uppsala, Sweden) all fractions with catalytic cholinesterase activity showed immunoreactive cholinesterase substance concentrations corresponding to a uniform specific catalytic activity of $1.2-1.3 \mathrm{kU} / \mathrm{mg}$ (fig. 3). Only fractions containing cholinesterase catalytic activity were detected by the ELISA assay.
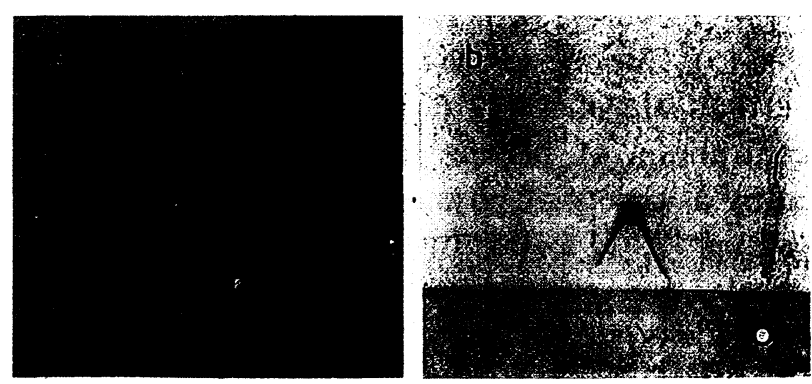

Fig. 2. Serum proteins separated by crossed immunoelectrophoresis, with non-specific, polyclonal rabbit antibodies against human plasma cholinesterase in the gel used for 2nd dimension.

(a) gel stained specifically for catalytic cholinesterase activity ( $\alpha$-naphthyl acetate/Fast Red TR).

(b) gel stained for HAH 2-1 immunoreactive cholinesterase by a peroxidase-conjungated rabbit antibody against mouse immunoglobulins (19). 




Fig. 3. Catalytic cholinesterase activity concentration (open circles) and immunoreactive cholinesterase substance concentration (filled circles) in plasma fractions separated by gel filtration (Sephacryl S-300, column: $60 \times 1.6 \mathrm{~cm}$, sample: $4 \mathrm{ml}$, flow: $5 \mathrm{ml} \mathrm{h}^{-1}$ ).

Two plasma proteins, acetylcholinesterase (EC 3.1.1.7) and thyroglobulin, contain homologous amino acid sequences with cholinesterase $(5,20,21)$. When estimated by an established enzyme antigen immunoassay (22), acetylcholinesterase in normal human plasma occurs in concentrations corresponding to about $3 \mathrm{U} / \mathrm{l}$. Purified red blood cell acetylcholinesterase (23) in an excess concentration (19.2 kU/1 (22)), or serum acetylcholinesterase in a 10 -fold concentration $(32 \mathrm{U} / 1)$ showed no interference in the ELISA assay $\left(\Delta \mathrm{A}_{\text {acetylcholinesterase: }} 0.012 ; \Delta \mathrm{A}_{\text {blank }}\right.$ : $0.011)$. A 100 -fold concentration $(5 \mathrm{mg} / \mathrm{l})$ of thyroglobulin also showed no interference $\left(\Delta \mathrm{A}_{\text {thyroglobulin }}: 0.028 ; \Delta \mathrm{A}_{\text {blank }}: 0.028\right)$.

\section{Results and Discussion}

The relation between cholinesterase catalytic activity concentration and immunoreactive cholinesterase substance concentration in randomly selected, freshly drawn serum samples from 33 healthy individuals (blood donors) is shown in figure 4. The figure shows a linear relationship $\left(r^{2}: 0.90\right)$ between immunoreac-

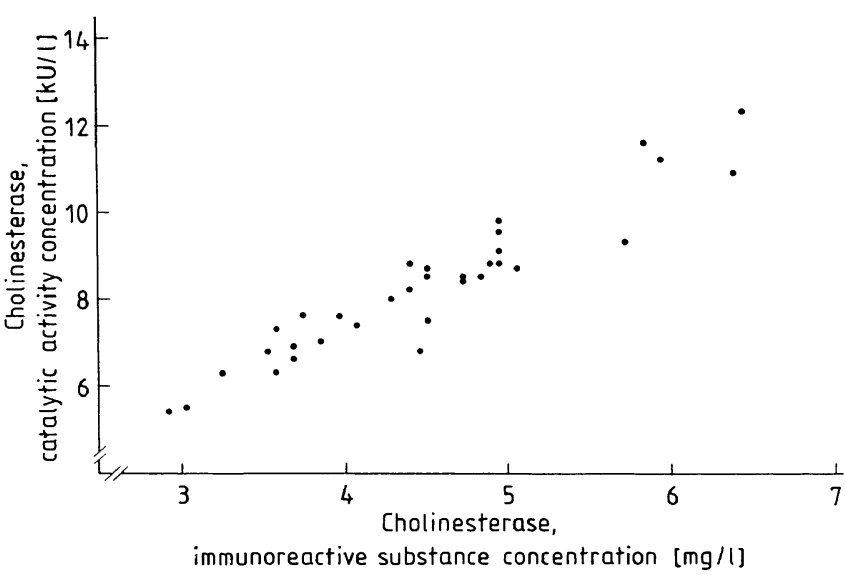

Fig. 4. Relation between catalytic cholinesterase activity concentration and immunoreactive cholinesterase substance concentration in random serum samples from 33 individuals; $\mathrm{y}=1.74 \mathrm{x}+0.40\left(\mathrm{r}^{2}=0.90, \mathrm{SD}_{\text {slope }}: 0.11\right.$, $\mathrm{SD}_{\text {intercept }}: 0.49$ ) tive substance concentration and catalytic activity concentration, without a significant ordinate intercept $(\mathrm{t}=0.82)$; mean specific catalytic activity: $1.74 \mathrm{kU} /$ $\mathrm{mg}$, SD: $0.11 \mathrm{mg} / \mathrm{l}$; mean catalytic cholinesterase activity concentration: $8.28 \mathrm{kU} / \mathrm{l}, \mathrm{SD}: 1.66 \mathrm{U} / \mathrm{l}$; mean immunoreactive substance concentration: $4.51 \mathrm{mg} / \mathrm{l}$, SD: $0.90 \mathrm{mg} / 1$.

A number of earlier studies $(13-16)$, reported native plasma cholinesterase substance concentrations of $5-15 \mathrm{mg} / \mathrm{l}$; however, this consensus is not surprising since all studies (performed by crossed immunoelectrophoresis $(13,14)$ or rockets $(15,16))$ were based on the same polyclonal antibody (A 032, Dakopatts, Glostrup, Denmark), and the same calibration material (Standard Human Serum Op. No. 166, Behringwerke, FRG). With a mean catalytic activity concentration of $8.45 \mathrm{kU} / 1$ (8), this substance concentration corresponds to a specific catalytic activity of about $0.8 \mathrm{kU} / \mathrm{mg}$.

In their study of purified human plasma cholinesterase, Lockridge \& $L a D u(24)$ found a specific catalytic activity of $170 \mathrm{U} / \mathrm{mg}$, measuring the catalytic activity according to Kalow \& Lindsay (25) with benzoylcholine as the substrate. Recalculation of this specific catalytic value, using published reference values (benzoylcholine at $25^{\circ} \mathrm{C}: 0.65-1.45 \mathrm{kU} / \mathrm{l}$ (3); butyrylthiocholine at $37^{\circ} \mathrm{C}: 8.45 \pm 1.94 \mathrm{kU} / \mathrm{l}(8)$ ), gives a value of about $1.4 \mathrm{kU} / \mathrm{mg}$ for the conditions used in our study.

In the present study, we find a mean specific catalytic cholinesterase activity in native serum samples of 1.74 $\mathrm{kU} / \mathrm{mg}$ (SD: $0.11 \mathrm{kU} / \mathrm{mg}$ ), which is about twice the specific catalytic activity previously reported (1316), and substantially higher than that reported for the purified enzyme (24). Such a high specific catalytic activity of plasma cholinesterase might be explained by

1., a previously overestimated cholinesterase substance concentration, e. g. due to interference by other proteins;

2., in agreement with our observations (fig. 3), a decreased catalytic cholinesterase activity of purified cholinesterase; or,

3., an underestimation of the purified cholinesterase substance concentration used for the final calibration of the ELISA described here.

We based our protein quantitation of the highly purified cholinesterase on the classical Folin reaction (as modified by Lowry et al. (18)) using a well characterized, pure bovine serum albumin (in the same buffer as the purified cholinesterase) as reference. A lower content of phenolic amino acids in cholinesterase 
would tend towards an underestimation of the protein mass concentration. However, the content of tyrosine (20 tyrosyl in 574 residues (21)) in cholinesterase is similar to that of bovine serum albumin (19 tyrosyl in 581 residues (26)), and cholinesterase even has a higher content of tryptophan (18 residues) than bovine serum albumin (2 residues). As a result, suggestions of an underestimation of the cholinesterase protein mass concentration used for final calibration of the ELISA can be rejected.

The enzyme immunoassay presented here allows a precise quantitation of immunoreactive cholinesterase substance concentration in native serum or plasma samples. The immunoassay has the following four important characteristics.

\section{References}

1. LaMotta, R. V. \& Woronick, C. L. (1971) Molecular heterogeneity of human serum cholinesterase. Clin. Chem. 17, $135-144$.

2. Brown, S. S., Kalow, W., Pilz, W., Whittaker, M. \& Woronick, C. L. (1981) The plasma cholinesterases: A new perspective. Adv. Clin. Chem. 22, 1-123.

3. Whittaker, M. (1986) Cholinesterase (Beckman, L., ed., Monographs in human genetics; vol. 11). Karger, Basel, pp. $1-132$.

4. Brock, A. (1989) Additional electrophoretic components of cholinesterase in plasma: A phenomenon of no importance to the total plasma cholinesterase activity. J. Clin. Chem. Clin. Biochem. 27, 429-431.

5. Lockridge, O. (1988) Structure of human serum cholinesterase. BioEssays 9, 125-128.

6. Evans, R. T., O'Callaghan, J. \& Norman, A. (1988) A longitudinal study of cholinesterase changes in pregnancy. Clin. Chem. 34, 2249-2252.

7. Lepage, L., Schiele, F., Guequen, R. \& Siest, G. (1985) Total cholinesterase in plasma: Biological variations and reference limits. Clin. Chem. 31, 546-550.

8. Brock, A. \& Brock, V. (1990) Plasma cholinesterase activity in a healthy population group with no occupational exposure to known cholinesterase inhibitors: relative influence of some factors related to normal inter- and intra-individual variations. Scand. J. Clin. Lab. Invest. 50 (in press).

9. Sidell, F. R. \& Kaminskis, A. (1975) Temporal intrapersonal physiological variability of cholinesterase activity in human plasma and erythrocytes. Clin. Chem. 21, $1961-1963$.

10. Augustinsson, K. B. (1971) Determination of activity of cholinesterases. In: Methods of biochemical analysis, vol. 19 (Glick, D., ed.). John Wiley and Sons Inc., New York, pp. $217-273$.

11. Silk, E., King, J. \& Whittaker, M. (1979) Assay of cholinesterase in clinical chemistry. Ann. Clin. Biochem. 16, $57-75$.

12. Weeke, B. (1970) The serum proteins identified by means of the Laurell crossed electrophoresis. Scand. J. Clin. Lab. Invest. 25, 269-275.

13. Krasilnikoff, P. A. \& Weeke, B. (1971) The intravascular mass of 21 serum proteins in normal mature and premature children. In: Protides of the biological fluids, vol. 18 (Peeters, H., ed.). Pergamon Press, Oxford, pp. 169-172.

14. Weeke, B. \& Krasilnikoff, P. A. (1972) The concentration of 21 serum proteins in normal children and adults. Acta Med. Scand. 192, 149-155.
1. It is based on a monoclonal antibody without detectable cross reactivity with other serum proteins (fig. 2).

2. Partially homologous proteins do not interfere significantly.

3. All fractions obtained by gel filtration which exhibit catalytic cholinesterase activity show parallel immunoreactivity (fig. 3).

4. The catalytic activity concentration is closely and linearly related to immunoreactive cholinesterase substance concentration (fig.4).

It can therefore be concluded that the immunoassay described here is a reliable method for specific, and valid quantitation of immunoreactive native plasma cholinesterase substance concentrations.

15. Brogren, C.-H. \& Bøg-Hansen, T. C. (1975) Enzyme characterization in quantitative immunoelectrophoresis: An enzymological study of human serum esterases. Scand. J. Immunol. 4, suppl. 2, 37-51.

16. Bøg-Hansen, J. C., Lorenc-Kubis, I. \& Bjerrum, O. J. (1980) Quantitative immunoelectrophoresis. A survey and some applications. In: Electrophoresis '79 (Radola, B. J., ed.). Walter de Gruyter and Co., Berlin, pp. 173-192.

17. Gallati, H. \& Brodbeck, H. (1982) Peroxidase aus Meerrettich: Kinetische Studien und Optimierung der Aktivitätsbestimmung mit den Substraten $\mathrm{H}_{2} \mathrm{O}_{2}$ und o-Phenylendiamin. J. Clin. Chem. Clin. Biochem. 20, $221-225$.

18. Lowry, O. H., Rosebrough, N. J., Farr, A. L. \& Randall, R. J. (1951) Protein measurement with the Folin phenol reagent. J. Biol. Chem. 193, 265-275.

19. Skjødt, K., Schou, C. \& Koch, C. (1984) Assay for the specificity of monoclonal antibodies in crossed immunoelectrophoresis. J. Immunol. Meth. 72, 243-249.

20. Chhajlani, V., Derr, D., Earles, B., Schmell, E. \& August, T. (1989) Purification and partial amino acid sequence analysis of human erythrocyte acetylcholinesterase. FEBS Letters 247, 279-282.

21. Lockridge, O., Bartels, C. F., Vaughan, T. A., Wong, C. K., Norton, S. E. \& Johnson, L. L. (1987) Complete amino acid sequence of human serum cholinesterase. J. Biol. Chem. 262, 549-557.

22. Rasmussen, A. G., Arends, J. \& Larsen, S. O. (1989) Evaluation and quality control of a monoclonal antibody based enzyme antigen immunoassay of acetylcholinesterase in amniotic fluid. Scand. J. Clin. Lab. Invest. 49, 503-512.

23. Brodbeck, U., Gentinetta, R. \& Ott, P. (1981) Purification by affinity chromatography of red cell membrane acetylcholinesterase. In: Membrane proteins. A laboratory manual (Azzi, A., ed.) Springer Verlag, Berlin, p. 85.

24. Lockridge, O. \& La Du, B. N. (1978) Comparison of atypical and usual human serum cholinesterase. J. Biol. Chem. 253, 361-366.

25. Kalow, W., Lindsay, H. A. (1955) A comparison of optical and manometric methods for the assay of human serum cholinesterase. Can. J. Biochem. Physiol. 33, 568- 574.

26. Peters, T., Jr. (1975) Serum albumin. In: The plasma proteins, 2nd ed., vol. 1 (Putnam, F. W., ed.) Academic Press, New York, pp. 133-181.
Axel Brock, MD, PhD
Department of Clinical Chemistry
Randers Centralsygehus
DK-8900 Randers 